\section{The Effect of Solo Last Friday Ride As A Sport Community in Solo}

RIANTO ARDI NUGROHO ${ }^{1}$

SUGIYANTO ${ }^{2}$

MUCHSIN DOEWES ${ }^{3}$

\begin{abstract}
The purpose of this study was to determine the implementation and organization of mass cycling event Solo Last Friday Ride,a mass cycling participants' creativity Identifying Solo Last Friday Ride, explaining the benefits of mass cycling participants Solo Last Friday Ride and communities around the mass cycling events Solo Last Friday Ride. The research was conducted in the city of Solo, Central Java. Using qualitative research and is presented using a phenomenological approach. The result of this research is the mass cycling event Solo Last Friday Ride bike community-initiated motion to move the mass cycling community as a means to stay in touch between cyclists, sports facilities, recreation, and promote the bicycle as a means of transportation back healthy and environmentally friendly. Organizing place prior to the coordination of internal discuss the themes and routes that bypassed, Creativity indicated participants adjust costumes and accessories in accordance with the theme, The benefits of participants was as a means of exercise, recreation, socializing, and reduce air pollution, while the general public around the activity is increased revenue.
\end{abstract}

Keywords: Solo last Friday ride, physical activity; sport for all; recreation; cycling

\section{Solo'da Bir Spor Topluluğu Olarak "Last Friday Ride" Aktivitesinin Etkisi}

$\ddot{O} z$

Bu çalışmanın amacı bir kitle bisiklet etkinliği olan "Solo Last Friday Ride" etkinliğinin kitle bisikletçiliği üzerine faydalarını açıklamak, kitle bisikletçileri katılımcılarının etkinliğe ilişkin durumlarını ortaya koymaktır. $\mathrm{Bu}$ çalışma nitel araştırma yöntemleri kullanarak ve fenomenolojik bir yaklaşımla sunulmaktadır. Araştırma sonucunda bir kitle bisikletçiliği etkinliği olan "Solo Last Friday Ride" etkinliğinin bisikletçiler tarafindan birbirleriyle irtibat halinde ve toplu hareket edebilmek adına başlatılan bir hareket olduğu, bir ulaşım aracı, spor aracı, rekreasyon aracı olarak bisikletin tanıtımını sağlamak ve çevre dostu olduğunu vurgulamanın hedeflendiği tespit edilmiştir. Etkinlik öncesi temaların oluşturulması ve rotaların belirlenmesi adına iç tartışöaların yapıldığı bir görüşme gerçekleşmekltedir. Katılımcıların kostüm ve aksesuarlarını belirlenen temeya göre yaratıcılıkları doğrulrusunda hazırladıkları görülmüştür. Etkinliğe katılanların sağlıdığı faydalar rekreasyon olayına katılmaları, egzersiz yapmaları, sosyalleşmeleri ve hava kirliliğini azaltmaları olarak tespit edilmiştir.

Anahtar Kelimeler: Solo last Friday ride, Fiziksel aktivite, Herkes için Spor, Rekreasyon, Bisiklet.

\footnotetext{
${ }^{1}$ Postgraduate Student at Sport Science Shool, Sebelas Maret University, Surakarta, ENDENOZYA rianto.ardi5@ gmail.com

${ }^{2}$ Lecturer at Sport Science Shool, Sebelas Maret University Surakarta, ENDENOZYA.

${ }^{3}$ Lecturer at Sport Science Shool, Sebelas Maret University Surakarta, ENDENOZYA.
} 


\section{INTRODUCTION}

Sport is a human motion activity according to specific techniques, in practice there are elements of the play, there is a sense of fun, done on time, and satisfaction. Sports is a series of regular exercise motion and planned that people consciously to improve the functional capacity, in accordance with the purpose of exercise Giriwijoyo (2013: 37). Sport is also a physical activity undertaken with a view to maintaining a healthy and strengthening muscles - the muscles of the body. sports utilizing the physical tools to develop human wholeness. In this connection mean that through physical, mental and emotional aspects also helped to grow, even with considerable emphasis on. It can be concluded that exercise is an activity range of motion of the body that are organized and planned that there are elements of play, rules or compete as well as the challenges and struggles are done having fun in your spare time to improve functional ability were carried out systematically in order to achieve goals was about to be achieved such as increased physical fitness, spiritual and social.

Sport is very much a role in different spheres of life that make up personality. As stated in the Law of the Republic of Indonesia Number 3 of 2005 on National Sports System Chapter VI, Article 17 states The scope of sports activities include: a) Sport education, b) Recreational Sports., And c) Sports achievements. Sports have meaning any body movement that are being made to improve the quality of life, while recreation is an activity that aims to be entertained, or just to relieve fatigue after facing various bustle and jobs. So that recreational sport that is a fun activity contains elements of positive movement performed activities indoor and outdoor dominated by elements of sports that can be fun. Recreational sports in the world of international known as the sport for all.

The underlying concept of sport for all can be described with less physical movement in today's modern life can be balanced by two methods alone, the first is to abolish vehicle technology standards and electricity that drives the engine and back to the way of life in the eighteenth century. And the second is to motivate people to become physically active as a lifelong habit of regularly and voluntarily. Sport for all movement aims to increase physical fitness and recreation gained in conducting the exercise and will be able to obtain health. Advances in technology today is already affecting patterns of human activity. Changes in lifestyle towards sedentary lifestyles are less and less physical activity health effects. Almatsier (2003: 144) suggests that physical activity is a physical movement performed by various muscles and systems that support it. The modern lifestyle has minimized the person's physical activity. The low level of physical activity can also increase the prevalence of obesity significantly. Obesity occurs when energy intake exceeds energy expenditure total including energy for physical activity. Scientific evidence clearly shows that regular physical activity of moderate intensity provide great health benefits. Some form of aerobic exercise such as cycling can be done three to five times a week to maintain health and fitness.

Recreational sports can be carried out by any person, educational units, institutions, associations, or sports organizations. Indonesian Community Recreation Sports Federation divides Sports Recreation scope is as follows: 1) Mass Sports, 2) Traditional Sports, 3) Special Sports, 4) Sports Challenge. Mass sport is a form of exercise done and followed a group or people. Included in one of the mass sport is cycling. Cycling also meets the necessary aerobic extras for the heart system but with less pressure on the limbs, According Carmichael (1996: 4-9). Goal leisure sports are all societies that adjusted for age. Sports Recreation directed to sosializing sport as an effort to develop public awareness in improving health, fitness, fun and social relations. Solo is one of the cities that has a program which is called a cyclist-friendly city. Besides, Solo begins to create an environmentally friendly city for the future. To achieve that goal, the government has to start from now on to provide the supported facilities. Therefore, the government has to 
know the existence phenomenon around the society to make the policy.

Recently, Solo people are attracted with the existence of mass cycling event which participated by a large number of masses. They name it as Solo Last Friday Ride. So the purpose of this study was describes implementation and organization of mass cycling events around the city in Solo Last Friday Ride. Identifying the creativity shown participants of mass cycling events around the city in Solo Last Friday Ride. Explaining the benefits of participants who take part in a mass cycling Solo Last Friday Ride and the general public who were around activities Solo Last Friday Ride.

\section{METHOD}

This research is held in Solo, Central Java. This research is applied qualitative research and presented using phenomenology approach. In a qualitative descriptive study, data collected mainly in the form of words, sentences or drawings that means more than just the frequency. Researchers stressed the record that describes the actual situation in order to support the presentation of data, According Sutopo (2002: 35). This research is focused to describe and analyze the phenomenon of mass cycling activity Solo Last Friday Ride started from the implementation, organization, participants' creativity, and the advantages for participants and society around the event. The data were collected using observation, in-depth interview, and documentation. Instruments used in data collection are video cameras and voice recorders, as well as interview guides. The validity of the data used technique trangulasi methods. Research conducted by a researcher using or similar data collection techniques but by using different techniques or data collection methods. The data presented in this study are valid because of the retrieval of data by different methods have shown similarities. Resource persons in this study amounted to 20 people, namely the General Chairman of Solo Sports Recreation Organization, Solo Last Friday Ride coordinator, Dishubkominfo, cycling participants, and the community around the movement of mass cycling. Besides, there were four phases used to analyze the data. Those were data collection, data reduction, data display, and drawing conclusions.

\section{FINDINGS}

The implementation and organization of mass cycling activity around the city at Solo Last Friday Ride

Mass cycling activity at Solo Last Friday Ride is a mass cycling community as a means of strengthening the brotherhood among cyclists, mode of sport, recreational facilities, and to promote the use of the bike as a form of health transportation and environmentally friendly. This activity is held once a month, every last Friday of the month. There are usually around seven thousand to ten thousand cyclists joined this activity. The participants consist of the people in Solo Raya and other citizens in any level of age and gender. They join together as one to cycle around Solo. This mass cycling activity starts at 7 p.m. from Manahan Solo Stadium. Then, the route is ended at two finish points, Ngarsopuro Crossroad and Vastenburg Castle.

It was found that there was no official committee who organize this mass cycling activity, there was a coordinator for Solo Last Friday Ride and Marshal. The internal coordination usually holds in two or three days prior to the due date of cycling activity. The internal coordination was held to discuss and decide the interesting theme; then, the coordinator had to coordinate with Dishubkominfo and police to report the selected route for cycling activity. 


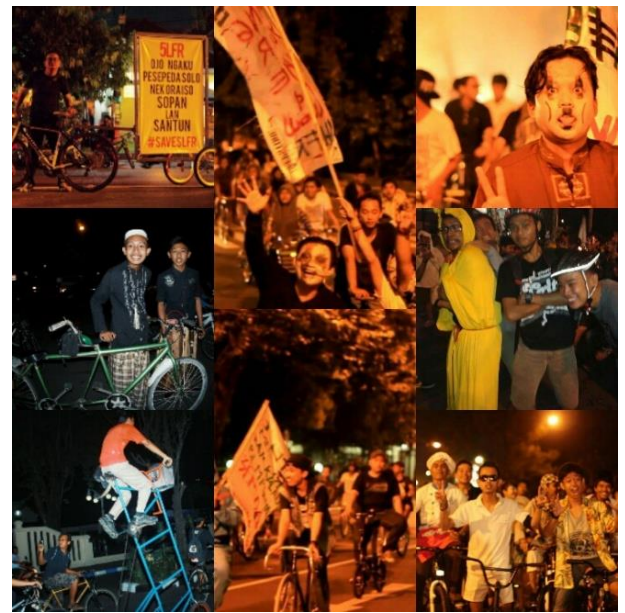

Image 1. Solo Last Friday Ride Mass Cycling
The participants showed their creativity by wearing unique costume and accessories that suit with the themes. Thus, all of the participants were able to choose and design their own costume. Most of the participants modified their bikes with colorful lamps, music on their bikes, or even with some posters. Those were the way how participants showed their creativity and enthusiasm to welcome the upcoming event.

The benefits got by the cyclists and society around Solo Last Friday Ride activity

The participants' creativity showed in Solo

Last Friday Ride

Table 1. The benefits of Solo Last Friday Ride Activity

The Cyclists

The Society Around The Event

To improve their physical fitness

Rise of economic growth especially for those who run a business related to bike and its equipment

To have fun

To have recreational activity

To eliminate fatigue from work and school through fun sports activity

Increased revenue for the traders and service

Could make the participants have more providers although they get it once a month.

friends by meeting many people

Could reduce the air pollution

Could be the best place for bike lovers to share many things by cycling together

\section{DISCUSSION AND RESULT}

Advances in technology today is already affecting patterns of human activity. Changes in lifestyle towards sedentary lifestyles are less and less physical activity, so that the effect on health. The modern lifestyle has minimized the physical activity performed by a person. The low level of physical activity can lead to health problems in the human body. Recreational 
sports geared to sports as an effort to develop public awareness in improving health, fitness, fun and social relations. Solo Last Friday Ride is one activity which is nothing but a destination of recreational sports.

This cycling event has been coordinated and regulated organization. According Torang Siregar (2014: 25), the organization is the role of the system, the flow of activities and processes that involve multiple people as acting that didescience to achieve a common goal. While understanding the organization according to Hasibuan (2004: 123) is a process of determining, grouping, and setting the various activities required to achieve a goal, put people on each of these activities, provide the tools necessary, establish the authority which relatively delegated to each individual who will perform the activity. With the organization in this activities it will make the goal of these activities can be run well and smoothly.

Mass cycling events around the city of Solo every Friday at the end of this month freeing participants to be creative and creativity. According to Conny R Semiawan (2009: 44) creativity is a modification of something that already exists into a new concept. In other words, there are two old concept that combined into a new concept. Meanwhile, according Utami Munandar (2009: 12), that creativity is the result of interaction between the individual and the environment, the ability to create new combinations, based on the data, information, or any items Unur existing or previously known, that is all the experience and knowledge that has been acquired a person during his life either in the school environment, family, and of society. Creativity can be shown to us in various ways one of which is through recreational sports activities. Participants are free to show their creativity in this cycling event, so attractive and able to attract people to join cycling. In addition Solo Last Friday Ride is not only beneficial for the participants, the public about any of these activities also benefit economically.

Mass cycling activity in Solo Last Friday Ride is a kind of community that introduces by cycling communities in Solo. This activity is aimed to invite the society to ride a bike as a means of sports activity, recreation, and gathering among cyclists. This activity is also as a medium to promote the use of a bicycle as a healthy mode of transportation and environmentally friendly. The coordination of this activity holds prior to the due date of cycling activity by having internal coordination to discuss and decide the interesting theme; then, the coordinator coordinate with Dishubkominfo and police to report the selected route for cycling activity.

Participants show their creativity by wearing unique costume and accessories that suit with the theme and sometimes the idea comes from the participants. Thus, all of the participants are able to choose and design their own costume. All participants are free showing their creativity and imagination since it does not harm themselves and others.

Cycling activity is beneficial to keep participants' physical fitness, have fun, have recreational activity, and eliminate exhaustion from any activity, make friends, reduce the air pollution, and as a gathering moment among cyclists. Meanwhile, the benefits obtained by the society around the event particularly are felt by the traders and service providers. The benefits are in terms of economic growth especially for those who run a business related to bike and its equipment, increased revenue for the traders and service providers although they get it once a month

\section{REFERENCES}

Almatsier, S. (2003). Prinsip Dasar Ilmu Gizi. Jakarta : PT Gramedia Pustaka Utama

Carmichael, B. (1996). Bugar Dengan Bersepeda. Jakarta : Raja Grafindo Persada.

Conny, R. S. (2009). Memupuk Bakat dan Kreativitas Siswa Sekolah Menegah. Jakarta: Gramedia.

Corbin, C. B. (2007). Fitness For Life. United States : Human Kinetics

Giriwijoyo, S., \& Sidik, D.Z. (2013). Ilmu Faal Olahraga. Bandung : Remaja Rosdakarya

Glassford, G. (1990). History Of Physical Activity Sciences. Urbana-Champaign. Human Kinetics Publisher.

Hasibuan, M. (2004). Manajemen. Jakarta : Bumi Aksara 
Nugroho, R. A., Sugiyanto, Doewes, M. / The Effect of Solo Last Friday Ride As A Sport Community in Solo (A Phenomenology Study of Mass Cycling Activity in Solo)

Kusumaningrum. (2015). Modul Olahraga Rekreasi. retrieveed May 3, 2017 from http://www.rinakurniawati.files.wordpress. com

Payne, V. G., \& Larry, D. I. (2012). Human Motor Development : A Lifespan Approach, Eight Edition. New York: Mc-Graw-Hill.

Schempp, P. G. (2003). Teaching Sport and Physycal Activity: Insights On The Road To Excellent.United States : Human Kinetics

Sutopo, H. B. (2002). Metodologi Penelitian Kualitatif. Surakarta: Universitas Sebelas Maret

Torang, S. (2014). Organisasi dan Manajemen. Bandung : Alfabeta.

Munandar, U. (2009).Pengembangan Kreativitas Anak Berbakat. Jakarta: PT.Gramedia.

Republic of Indonesian Law No. 3 Year 2005. National Sports System. Jakarta : CV. Eko jaya 